Bol. Acad. peru. leng. 63. 2018 (223-232)

\title{
EL MAESTRO DE TARCA VISTO POR EL MUCHACHO DE MASATEPE
}

(Contestación al discurso de ingreso de Sergio Ramírez el 15 de mayo de 2003 como miembro de número de la Academia Nicaragüense de la Lengua)

\author{
Jorge Eduardo Arellano
}

Academia Nicaragüense de la Lengua

$\begin{array}{ll}\text { Fecha de recepción: } & 13 / 03 / 2018 \\ \text { Fecha de aceptación: } & 31 / 05 / 2018\end{array}$

La Academia Nicaragüense de la Lengua da su cálida bienvenida al narrador más sobresaliente del país en la segunda mitad del siglo recién pasado y el principio del actual. Este mérito indiscutible, demostrado por una conciencia y un ejercicio sin paralelo en el área centroamericana, le basta a Sergio Ramírez para acreditarse su sitial en nuestra incorporación.

Pero no solo ha desplegado esta trayectoria creadora, sino también el inevitable prestigio de su figura política consolidada en 1977, cuando 
encabezó el Grupo de los Doce (formado por intelectuales, empresarios, sacerdotes y dirigentes civiles) en lucha contra el régimen de Anastasio Somoza Debayle; integró la Junta de Gobierno de Reconstrucción Nacional; fue elegido vicepresidente en 1984; sufrió la debacle de su partido en 1990; jefeó su bancada opositora; renunció al mismo en 1995, fundó su propio partido como opción política renovadora y perdió las elecciones de 1996 — teniendo, acaso como nadie en América, «más lectores que electores»— hasta retirarse, al parecer definitivamente, de la política partidaria.

Porque, como es muy sabido, en Sergio ha sido consubstancial la simultánea proyección de sus dos praxis: la escritura literaria y la militancia política. Escritura y militancia que, fundidas en una sola personalidad, no es posible desintegrar, pero sí deslindar. Por eso quien se incorpora a nuestra cofradía de lingüistas y literatos es el narrador por antonomasia que eligió ser desde los primeros años 60 . Un novelista que ha cumplido con destreza inusual sus metas propuestas y un consumado cuentista maestro. Asimismo, otras facetas destacan en su carrera y gestión culturales.

Con el riesgo de olvidar algún dato, recordaré al fundador y mentor del Grupo VENTANA y de su revista en 1960, al lado del inolvidable Fernando Gordillo (1941-1967); al renovador de la burocracia universitaria a nivel centroamericano cuando fue nombrado por dos períodos, en 1968 y 1976, secretario general del Consejo Superior Universitario de Centroamérica (CSUCA); al gestor de Educa, editorial que hizo posible una integracióntambién de dimensión ístmica; al intérprete sociológico del proceso cultural de nuestros balcanizados países, logro que superó los reduccionismos dependentistas de moda; al compilador, difusor y estudioso del corpus documental, acciones e ideas de Augusto César Sandino —El Muchacho de Niquinohomo-, cuyas numerosas ediciones culminaron en un volumen de 667 páginas de la Biblioteca Ayacucho titulado Pensamiento político: aporte sin par a la herencia histórica y espiritual de nuestra América.

Asimismo, no es posible olvidar al antólogo e investigador sistemático del cuento centroamericano y al prologuista y editor del 
clásico salvadoreño Salvador Salazar Arrúe (Salarrué), bajo el título de El Ángel y el Espejo y el sello de la misma Colección Ayacucho de Caracas; al cinéfilo y cronista berlinés que dejó plasmadas sus experiencias en las columnas «Eurorama 75» y «Ventana»; al coordinador de ese experimento que integró a los principales escritores del istmo La Prensa Literaria Centroamericana, dirigida por Pablo Antonio Cuadra; al exégeta e ideólogo del proyecto revolucionario que insurgió y floreció, se deterioró y feneció en los convulsivos años 80; al diestro transcriptor testimonial de las experiencias colectivas de esa igualmente intensa e irrepetible década; al fundador de esa otra vasta realización masiva que fue la Editorial Nueva Nicaragua, sin precedentes en nuestra historia; al ensayista que ha reflexionado sobre su doble experiencia vital ( «la literatura y la política en Nicaragua — he declarado — son hermanas siamesas»). Por último, al pensador orgánico y organizado que se encuentra en la cima de su existencia.

A Sergio, pues, le protege un armazón inexpugnable: el oficio literario, al que se ha entregado apasionadamente —incluyendo las horas que Tulita, su mujer, inventó para ejercerlo cuando era gobernante- y - es necesario subrayarlo- con mucha imaginación. Y ese oficio le ha producido muchas alegrías y satisfacciones. He aquí las imprescindibles: el Premio Latinoamericano de Cuento de la revista Imagen, también de Caracas, por su libro De tropeles y tropelías (1973), una colección de fábulas que combinan la ironía furiosa y la gracia sutil; la categoría de finalista que mereció su novela ¿Te dio miedo la sangre? (1978) dentro del quinquenal Premio Latinoamericano Rómulo Gallegos; el Dashie Hammett en 1990 que recibió su novela Castigo divino (1988), llevada a la televisión colombiana; el Laure Bataillon al mejor libro extranjero en Francia que recibió su otra novela, la más entrañable suya: Un baile de máscaras (1995); el Internacional de Novela Alfaguara, otorgado en Madrid por un jurado que presidió Carlos Fuentes a su Margarita, está linda la mar, y —uno más reciente- el Latinoamericano de Novela José María Arguedas, obtenido por esa misma novela en La Habana.

Su hoja de vida incluye otros títulos muy conocidos. Mas no resulta superfluo anotarlos durante esta memorable ocasión en la que 
me ha correspondido el honor de contestar su discurso de incorporación a nuestra Casa aristósofa que presido, a la cual Sergio dará más brillo y esplendor. Aludo a Cuentos (1963), primicia editada por Mario Cajina Vega en su Editorial Nicaragüense e ilustrada por Leoncio Sáenz, que definió su vocación de narrador comprometido y realista; Nuevos cuentos (1969), una reconfirmación moderna de la misma y de su destino, que ya ofrece piezas antológicas como «El Centerfielder», cuya última presencia se localiza en la obra 16 Cuentos Latinoamericanos (1992), y Tiempo de fulgor (1970), su despunte novelístico macondiano, pero al mismo tiempo revelador de la intrahistoria leonesa —uno de sus letmotivs—, sobre el cual publiqué una reseña que fue consignada en la primera aproximación académica de su obra: La técnica narrativa en Sergio Ramírez (UNAN, Managua, 1971), de la hoy doctora Nydia Palacios Vivas.

A estas tres obras siguieron no pocas más en las décadas siguientes. Unas consistieron en selecciones de cuentos, como Charles atlas también muere (1976), título también de otro cuento antológico cuya primicia nos había cedido especialmente —a Gladis Miranda y a mí- para nuestro boletín literario El Güegüense (N. ${ }^{\circ}$ 1, febrero, 1971). Este año apareció su acabada biografía de Mariano Fiallos Gil, clave para comprender el entorno histórico de su decisiva formación, lo mismo que la impronta magisterial que le marcó aquel humanista beligerante. De todos sus ensayos, ese es el que personalmente prefiero, en parte porque ofrece pistas para seguir el desarrollo político, intelectual y narrativo del Muchacho de Masatepe, como lo llamó en una modesta semblanza Fernando Centeno Zapata. Por ejemplo, la concepción de Castigo divino ya está prefigurada, definida en la página 31 de ese libro esclarecedor. Cito, tras una síntesis que Sergio realiza de los hechos que años después llevaría a su máxima capacidad fabuladora:

Con esta lúgubre historia folletinesca, de envenenamientos misteriosos y truculentas historias de amor que salieron después a relucir en la trama del proceso, se sacudió por casi un año la modorra provincial de León, que tuvo [Fiallos Gil] oportunidad de vivir y presenciar lo que solo era antes objeto de las historietas por entrega de fines del siglo xix. El héroe, como un truco legítimo de folletín, se convirtió de pronto en villano. 
Y, así, Sergio revitalizaría en Castigo Divino el género del folletín, asimilándolo a sus dones narrativos, a sus prácticas intertextuales, a su humor truculento, a su crítica vitriólica. Como observó Carlos Fuentes, en esa novela — no exenta, como una gran parte de su obra, de recursos cinematográficos - el nicaragüense «extiende la técnica flaubertiana a una sociedad entera, verdadero microcosmos de la América Central».

Otras listas de libros y folletos suyos pueden consultarse en la Nicaraguan National Bibliography/1800-1978 que suma 19 entradas, en la Bibliografía Nacional Nicaragüense/1979-1989 con 35, y en las subsiguientes que edita la Biblioteca Nacional «Rubén Darío». Ineludibles, entre ellas, el excelente cuentario Clave de sol (1992), donde figura «Juego Perfecto»-literalmente, un cuento perfecto como el que le inspiraría más tarde el jonronero nicaragüense Pedro Selva-; la colección de ensayos Oficios compartidos (1994); el prólogo a la edición conmemorativa del 98, de España contemporánea (1998) de Rubén Darío, y otro —más extenso y afín a su naturaleza de narrador - a la edición crítica de Mulata detal (2001), la famosa novela de Miguel Ángel Asturias, publicada en la colección Archives de París.

Igualmente, ineludibles son sus recientes títulos: el Retrato de familia con violín (1997), una breve memoria de sus antecesores filarmónicos; Adiós muchachos (1999), testimonio personal, crítico y desgarrador, mesurado y objetivo que se estructura y se lee como una amenísima novela; Mentiras verdaderas (2001), conferencias sobre la creación literaria dictadas en la cátedra «Julio Cortázar» de la Universidad de Guadalajara; Catalina y Catalina (2001), otro cuentario del taller Ramírez Mercado, y Sombras nada más (2002), su sexta novela. En ellas, Sergio despliega sus veteranas virtudes de narrador: lengua propia, temática singular, intensidades rítmicas y verosimilitud llevada a lo fantástico.

Este es el hombre que ocupará la silla «G» de nuestra Academia, heredándola de Pablo Antonio Cuadra, maestro literario cuyo ejemplo de trabajo, actividad promocional y autoridad moral, rigor y amor por la perfección le sirvieron — como a pocos de su generación- en sus 
inicios de escritor, como lo reveló a raíz de la desaparición física de aquel patriante, a quien Sergio ha llamado «El Maestro de Tarca».

Mas no quisiera proseguir el recuento de nuestra laudatio de Sergio Ramírez - cuyos múltiples reconocimientos sería fatigoso enumerar, pues abarcan condecoraciones, doctorados honoris causa, jurados de certámenes internacionales, cátedras en universidades de Estados Unidos, México, Alemania, Francia y España- sin referirme, aunque sea brevísimamente, al tema de su discurso como recipiendario: la narrativa de Pablo Antonio cuadra.

Ya ha sido escuchado con suma atención y no pretendo resumir su agudo análisis. Basta señalar su punto de partida: el desajuste que «imprimió Darío a su tierra natal» al engendrar, sin culpa alguna de su parte, una «tierra de poetas», no de narradores. Son varias las causas que explican dicho fenómeno, varias de ellas desarrolladas por Sergio. En ese orden, magnifica el prestigio popular del Darío a su regreso triunfal, como profeta en su tierra, a finales de 1907; prestigio «entre la gente iletrada, el Darío de los carretoneros, las verduleras y los mozos de cordel». En pocas palabas, de los bazuqueros. Es decir, un Darío apócrifo, asumido e inventado por la mentalidad colectiva del bajo pueblo que se le apropia distorsionándolo, atribuyéndole versos cursis y obsceno, aspecto que Sergio ha explotado desde ¿'Te dio miedo la sangre? (p. 130), poniéndolo en boca de uno de sus personajes como «bolo» (ebrio consuetudinario) y «gran vulgar». Leyendas que nada tienen que ver con la realidad, solo con la ficción, pues el Bardo Rei bebía como un nicaragüense normal y nunca hasta embriagarse - lo puntualizó en 1930 la inmensa literata chilena Gabriela Mistral, primer premio Nobel de América Latina- «no fue más allá de la ebriedad del hombre de nuestra raza y, con ella de la inglesa y de la rusa, que forman el trío de este frenesí».

Además, Darío no disminuía su decoro exterior — mantenido durante muchos años de vida social en América y Europa-, ni redujo su hábito laborioso. «Verlaine dejó menos labor — agrega Mistral—, al igual 
que Poe; es decir, aquellos que para el vulgo comparten el tabladillo de la embriaguez. En vez de esto tuvimos en Darío un trabajo constante de escribir, otro cotidiano de leer para informarse. Leyó lo clásico sustancial y leyó todo lo moderno, tanto leyó que no hemos tenido cabeza más puesta al día que la que nos prueban Los Raros y los libros numerosos de crítica literaria».

Entrando al mundo narrativo de Pablo Antonio Cuadra, Sergio presenta el peso de la cultura rural o provinciana que subyace en él. Y, no podía ser de otra manera, si se recuerda que fue hasta en la década de los cincuenta del siglo $\mathrm{xx}$ - cuando el autor de Por los caminos van los campesinos cifraba en los cuarenta y pico años- que Nicaragua tuvo su «despegue» modernizador. Con todo, nuestro recipiendario reconoce en los poetas nicaragüenses contemporáneos — desde José Coronel Urtecho hasta Fernando Silva- a «grandes narradores». Y uno de ellos, sin duda, es «El Maestro de Tarca». Como Darío, éste ejecuta tanto la narración en prosa como la narrativa en verso. Ya los había advertido el colombiano Eduardo Cote Lemus: «En los poemas de Pablo Antonio Cuadra siempre sucede algo». Y, es a partir de los Cantos de Cifar (1971) que Sergio queda impactado por la narrativa en verso y prosa de Pablo Antonio, cuyos textos que en su discurso ejemplifica y glosa, resumiendo sus argumentos, ponderándolos y especificando que «la poesía extiende sus alas sobre su obra en verso y su obra en prosa, como si al regresar a los orígenes del arte de escribir y describir no necesitáramos de esa división entre prosa y poesía».

Con este planteamiento crítico, Sergio comenta que Esos rostros que asoman en la multitud (1974) es «un título que empareja tanto narraciones en verso como narraciones en prosa»; Doña Andreíta y otros retratos(1976), y las Prosas de Cifar (1978), sabiendo su autor que este Cifar es su mejor personaje y el Gran Lago su mejor escenario. Aunque patriarcal, el mundo narrativo y telúrico de Pablo Antonio está saturado de humanismo, «de apego no solo a la tierra — cito una vez más-, sino también y - sobre todo- a quien la habita, personajes desvalidos de toda fortuna, y expuestos todos a la contaminación. Campesinos de agua dulce, campesinos de ribera, campesinos de tierra firme y de los 
llanos». Es decir, Pablo Antonio Cuadra, fundamentalmente, plantea una narrativa de la compasión cristiana, naturalmente.

Así, por ejemplo, Sergio se adentra tanto en el personaje Nicanor Villagra, de Agosto — cuento forjado de hermosura barroca, majestuosa, precisa, transparente - como en todos los de ese señero drama rural que es Por los caminos van los campesinos (1971), como ya lo han escuchado. De hecho, los párrafos extensos, profundos, admirables párrafos de su discurso los ha destinado al prólogo de las Obras de Pablo Antonio Cuadra - la correspondiente a narrativa y a teatro- que editará este año, en su Colección Cultural de Centroamérica, la Fundación Vida del Banco UNO.

Al respecto, no todo el Pablo Antonio Cuadra narrador se haya presente en ese volumen que ha preparado su nieto, amigo fraterno y colega Pedro Xavier Solís. Faltan sus tres «Cuentos de muertos» (1944) que infunden una categoría culta a la arraigada fuente de nuestra literatura oral: los cuentos de aparecidos. Por algo fueron premiados en un certamen —el año referido- del Círculo de Letra Nuevos Horizontes. A estos siguieron otros que anticipaban el ámbito de los de Cifar y uno de ellos, por lo menos, apareció como «Ulises y el cíclope» en la revista Centroamericana (N. ${ }^{\circ}$ 4, abril-mayo, junio, 1955: 61-65) de Carmen Sequeira y luego en la obra antológica Panorama del cuento centroamericano (1960) con el título reducido a «El cíclope», posteriormente incluido en otra antología. Sei racconti nicaragïense (Roma, 1978) de Franco Cerutti.

El mismo Sergio seleccionó otro cuento representativo de Pablo Antonio cuadra: «Nuevo régimen» (1967), en su primera Antología del cuento nicaragüense que inserté como libro del mes de Revista Conservadora del Pensamiento Centroamericano (N. ${ }^{\circ} 109$, octubre, 1969: 44-47). Vale la pena rescatarlo.

\section{III}

Para concluir, es necesario aclarar o informar acerca de tres puntos. El primero, que nuestra Academia — desde hace unos diez años- es lo 
que menos parecido a un «Club de la Lengua» y que está constituida por notables personalidades, muy conocidas en nuestro medio e, incluso, en el exterior. Bastaría mencionar a Carlos Tünnermann Bernheim, educador de talla continental, que ocupa la subdirección desde enero de 2002 y a Alejandro Serrano Caldera, el filósofo postmoderno de Nicaragua. Ambos - más a cercanos a Sergio que yo, aunque siempre mantuve una distancia respetuosa con él, aún en los momentos más duros de los 80 - hubieran contestado mejor su discurso.

El segundo, que la Real Academia Española también es algo muy distinto de lo que era hace veinte años. Modernizada y dinámica, realiza unas tareas de inconmensurable valor para fortalecer la unidad de nuestro idioma y, consecuentemente, se mantiene en permanente relación con sus homólogas del continente americano. Ya está lejanísima de aquella decimonónica y fosilizada que Darío a sus quince años combatiera y a los 34 atacara a la mayoría de sus ilustres miembros con burlas y epigramas en el capítulo «Los inmortales» (título irónico tomado de León Daudet) de su España contemporánea (1901).

$\mathrm{Y}$, tercero, la frase que muchos le atribuyen a Darío: «De las Academias, líbranos señor» es incorrecta porque nunca se ha leído en su verdadero contexto ni se ha realizado, solo hasta hace poco, su fijación textual. Aunque Darío intrínsecamente haya sido antiacademicista, en su «Letanía de nuestro Señor Don Quijote», uno de los magnos textos de Cantos de vida y esperanza (1905), dijo otra cosa en tres versos, que deben leerse sin puntuación, como lo revela su manuscrito:

De las epidemias de horribles blasfemias de las Academias, líbranos, señor.

Su destinatario — lo reitero- era Don Quijote, que — según el líder del modernismo de ambas orillas de la lengua— no debía ni podía morir. 
https://doi.org/10.46744/bapl.201801.009

Finalmente, representando a nuestra Academia —en la que hacías mucha falta - te agradezco, Sergio, por unirte a nosotros. Con tu aporte, seguiremos con mayor firmeza y confianza nuestras tareas. 